\title{
The acid-stress response in Lactobacillus sanfranciscensis CB1
}

\author{
Maria De Angelis, ${ }^{1}$ Luca Bini, ${ }^{2}$ Vitaliano Pallini, ${ }^{2}$ Pier Sandro Cocconcelli ${ }^{3}$ \\ and Marco Gobbetti ${ }^{1,4}$
}

Author for correspondence: Marco Gobbetti (Dipartimento di Protezione delle Piante e Microbiologia Applicata).Tel: +3980 5442949. e-mail: gobbetti@unipg.it

1 Dipartimento di Scienze degli Alimenti, Sezione di Microbiologia Agroalimentare, Università degli Studi di Perugia, S. Costanzo, 06126 Perugia, Italy

2 Dipartimento di Biologia Molecolare, Università degli Studi di Siena, Italy

3 Istituto di Microbiologia, Università Cattolica del Sacro Cuore, Piacenza, Italy

4 Dipartimento di Protezione delle Piante e Microbiologia Applicata, Università degli Studi di Bari, Via G. Amendola 165/a, 70126 Bari, Italy

\begin{abstract}
Lactobacillus sanfranciscensis CB1, an important sourdough lactic acid bacterium, can withstand low pH after initial exposure to sublethal acidic conditions. The sensitivity to low pH varied according to the type of acid used. Treatment of $\mathbf{L b}$. sanfranciscensis CB1 with chloramphenicol during acid adaptation almost completely eliminated the protective effect, suggesting that induction of protein synthesis was required for the acid-tolerance response. Two constitutively acid-tolerant mutants, CB1-5R and CB1-7R, were isolated using natural selection techniques after sequential exposure to lactic acid (pH 3.2). Two-dimensional gel electrophoresis analysis of protein expression by non-adapted, acid-adapted and acid-tolerant mutant cells of $\boldsymbol{L} b$. sanfranciscensis showed changes in the levels of 63 proteins. While some of the modifications were common to the acid-adapted and acid-tolerant mutant cells, several differences, especially regarding the induced proteins, were determined. The two mutants showed a very similar level of protein expression. Antibodies were used to identify heat-shock proteins DnaJ, DnaK, GroES and GrpE. Only GrpE showed an increased level of expression in the acidadapted and acid-tolerant mutants as compared with non-adapted cells. The $\mathbf{N}$ terminal sequence was determined for two proteins, one induced in both the acid-adapted and mutant cells and the other showing the highest induction factor of those proteins specifically induced in the acid-adapted cells. This second protein has $60 \%$ identity with the $\mathbf{N}$-terminal portion of $\mathrm{YhaH}$, a transmembrane protein of Bacillus subtilis, which has 54 and $47 \%$ homology with stress proteins identified in Listeria monocytogenes and Bacillus halodurans. The constitutively acid-tolerant mutants showed other different phenotypic features compared to the parental strain: (i) the aminopeptidase activity of CB1-5R decreased and that of CB1-7R markedly increased, especially in acid conditions; (ii) the growth in culture medium at $10^{\circ} \mathrm{C}$ and in the presence of $5 \% \mathrm{NaCl}$ was greater (the same was found for acid-adapted cells); and (iii) the acidification rate during sourdough fermentation in acid conditions was faster and greater.
\end{abstract}

Keywords: lactic acid bacteria, acid-tolerant mutant, protein expression, sourdough

\section{INTRODUCTION}

It is well known that microbial growth is a self-limiting process and is often suboptimal in nature compared to controlled conditions in the laboratory. Natural stresses like acidity and sometimes starvation are generated by

Abbreviations: 2D, two-dimensional; NA, nitroanilide. cell growth itself, while other stresses (e.g. temperature, osmotic shock or oxygen) are induced by the environment (Foster, 1999).

Studies on the adaptive physiology of lactic acid bacteria facilitate efforts to improve their activity in industrial applications. Most studies have considered Lactococcus lactis subsp. lactis because of its extensive use in dairy products. Heat-shock proteins DnaK, DnaJ and GrpE, which constitute a three-component chaperone system 
in Escherichia coli (Diamant \& Goloubinoff, 1998), as well as GroES and GroEL, have been identified in $L c$. lactis (Rallu et al., 1996), where they are necessary for proper refolding of proteins, and/or for targeting denatured proteins for degradation by cytoplasmic proteases. The RecA protein, which is important in the response to several environmental stresses such as DNA damage, oxygen and heat stress (Duwat et al., 1995), and a large protein complex which includes ClpP (caseinolytic protease) and is involved in degrading misfolded proteins (Frees \& Igmer, 1999), were also studied in Lc. lactis. $\mathrm{H}^{+}$-ATPase is another of the acid tolerance response proteins induced by acid intracellular pH (O'Sullivan \& Condon, 1999). Cellular metabolic pathways are closely related to stress response, and the flux of particular metabolites, notably guanine and phosphate, may be implicated in stress responses of lactococci (Duwat et al., 1999). The adaptive response to several stresses varied between Lc. lactis subsp. lactis and subsp. cremoris; the former can adapt better to acid, bile-salt and freezing stresses (Kim et al., 1999). As a conclusion, while some of the stress-induced genes seem to be genuinely specific, others are induced by a wide variety of stresses, and are thus thought to be general stress-response genes (Hecker et al., 1996).

Lactobacilli have received less attention than Lc. lactis. The $h \operatorname{tr} A$ gene, encoding a stress-inducible HtrA-like protein, has been cloned, sequenced and characterized in Lactobacillus helveticus CNRZ32 (Smeds et al., 1998). After thermotolerance experiments, heat-shock proteins such as DnaK, GroEL, ClpB and GrpE were detected in Lactobacillus acidophilus, Lactobacillus casei and Lb. helveticus (Broadbent et al., 1997). The growth of Lactobacillus plantarum is more severely inhibited by salt stress than by equi-osmolar concentrations of sugars, which reflects the inability of the cells to accumulate enough $\mathrm{K}^{+}$(or $\mathrm{Na}^{+}$) to restore turgor, as well as to prevent deleterious effects of the electrolytes intracellularly (Glaasker et al., 1998). Acid- and bileresistant variants of $L b$. acidophilus capable of growing at $\mathrm{pH} 3.5$ with $0.3 \%$ bile were isolated using natural selection techniques after sequential exposure to hydrochloric acid (Chou \& Weimer, 1998).

To our knowledge, no studies have been published on the stress responses of sourdough lactobacilli. The study of the stress responses of sourdough lactic acid bacteria is worthwhile, to improve the use of this natural starter, to have a more complete knowledge about the physiology of these industrial bacteria and to make a comparison between lactic acid bacteria which populate different environments and dairy strains. During routine use, sourdough bacteria are mainly subjected to cold and acid stresses which are inherent to refrigerated storage (about $24-48 \mathrm{~h}$ at $4{ }^{\circ} \mathrm{C}$ ) of sourdough $(\mathrm{pH}$ about 3.4-4.0) after fermentation and before being used. Such stresses interfere with the constant microbial composition and with the performance of the sourdough (Gobbetti, 1998).

In this paper, we describe the acid-stress response of Lactobacillus sanfranciscensis CB1, the isolation of constitutively acid-tolerant mutants, the improved growth properties of acid-adapted and mutant cells in restrictive environmental conditions $\left(10{ }^{\circ} \mathrm{C}\right.$ and $5 \%$ $\mathrm{NaCl}$ ), the modification of the protein levels after acid adaptation, the identification in the mutants of DnaK, DnaJ, GrpE and GroES proteins, the N-terminal sequencing of proteins and their homology with previously identified stress proteins, and the use of mutants to improve sourdough fermentation in specific conditions.

\section{METHODS}

Bacterial strain and growth conditions. Lb. sanfranciscensis CB1 from the Culture Collection of the Dipartimento di Scienze degli Alimenti, Sezione di Microbiologia Agroalimentare, University of Perugia, Italy, was used. Cultures were grown at $30{ }^{\circ} \mathrm{C}$ in modified MRS, which contained $0.5 \%$ maltose, $1.0 \%$ peptone, $0.5 \%$ yeast extract, $1 \mathrm{ml}$ Tween $80 \mathrm{l}^{-1}, \quad 0 \cdot 2 \% \quad \mathrm{~K}_{2} \mathrm{HPO}_{4}, \quad 0 \cdot 2 \%$ ammonium citrate, $0.02 \%$ $\mathrm{MgSO}_{4}$ and $0.005 \% \mathrm{MnSO}_{4}$. The pH of the modified MRS was 6.4 and, unless otherwise stated, it was maintained constant by the on-line addition of $1 \mathrm{M} \mathrm{NaOH}$.

Adaptation conditions and measurement of acid tolerance. Cells grown at a constant $\mathrm{pH}$ of 6.4 were harvested in the mid-exponential growth phase $\left(\mathrm{OD}_{620} 0 \cdot 6\right)$. To induce acid adaptation (adapted cells), cells were resuspended at the same $\mathrm{OD}_{620}$ value in fresh medium, which prior to use was adjusted to $\mathrm{pH} 5 \cdot 0$ by approximately $14 \mathrm{mM}$ lactic acid. Control cells were resuspended in fresh medium at $\mathrm{pH} 6.4$ (non-adapted cells). After incubation at $30^{\circ} \mathrm{C}$ for $1 \mathrm{~h}$, control and adapted cells were harvested by centrifugation, washed and resuspended in modified MRS acidified to $\mathrm{pH} 3 \cdot 2,3 \cdot 4,3 \cdot 6,3 \cdot 8$ and $4 \cdot 0$ with concentrations of lactic acid which ranged from approximately 43 to $132 \mathrm{mM}$. The cell density was then adjusted to $\mathrm{OD}_{620} 1.0$ and the cultures were incubated for $10 \mathrm{~h}$ at $30^{\circ} \mathrm{C}$. Constitutively acid-tolerant mutant cells (see below), were used in the same conditions as the control. Challenges at $\mathrm{pH} 3.4$ were also carried out by setting the $\mathrm{pH}$ with approximately $41 \mathrm{mM} \mathrm{HCl}$ and with a mixture of approximately $86 \mathrm{mM}$ lactic acid and approximately $38 \mathrm{mM}$ acetic acid (molar ratio approx. $2 \cdot 3$ ). The $\mathrm{pH}$ range $(3 \cdot 2-4 \cdot 0)$ and the concentrations of lactic acid or a mixture of lactic and acetic acids were in line with the $\mathrm{pH}$ values and the concentrations of metabolic end-products which are usually found after sourdough fermentation (Gobbetti, 1998). When the acid tolerance was measured in the presence of acid or mixtures other than lactic acid alone, the adaptation of cells at $\mathrm{pH} 5.0$ was also induced with the corresponding acid or mixture of acids.

Chloramphenicol $\left(100 \mu \mathrm{g} \mathrm{ml}^{-1}\right)$ was used in the experiments according to Hartke et al. (1996). It was added to midexponential-phase cells which were harvested and resuspended in fresh medium at $\mathrm{pH} 6.4$ and held at $30^{\circ} \mathrm{C}$ for 10-60 min. After incubation, the cells were harvested by centrifugation, washed with fresh medium, subjected to acid adaptation and used for acid challenges. Chloramphenicol was also added to cells directly during adaptation.

Cell numbers were determined by plating on SDB agar medium (Kline \& Sugihara, 1971) immediately after resuspension and at different time intervals. Numbers of c.f.u. were determined after $48 \mathrm{~h}$ incubation at $30^{\circ} \mathrm{C}$. The number of surviving micro-organisms was calculated as a percentage of the cell number at time zero. The tolerance factor corresponded to the ratio of the survival of adapted cells to that of control cells. 
Isolation of acid-tolerant mutants of $\boldsymbol{L b}$. sanfranciscensis CB1. The treatment for isolation of acid-tolerant mutants was according to the protocol of O'Driscoll et al. (1996). Exponential-phase cells of Lb. sanfranciscensis CB1 grown in modified MRS at constant $\mathrm{pH}$ of 6.4 were harvested by centrifugation and resuspended in the same medium at $\mathrm{pH} 3 \cdot 2$. After incubation for $24 \mathrm{~h}$ at $30^{\circ} \mathrm{C}$, the cells were harvested, washed in quarter-strength Ringer's solution and plated in modified MRS agar, $\mathrm{pH} 5 \cdot 6$, at $30^{\circ} \mathrm{C}$ for $36 \mathrm{~h}$. Individual survivors were further grown in modified MRS broth at constant $\mathrm{pH}$ of 6.4 (exponential growth phase) and subsequently subjected to five repeated treatments to increase the tolerance at the lethal $\mathrm{pH}$. In this manner, seven mutants constitutively resistant to low $\mathrm{pH}$ in the absence of induction were isolated. Two of them, designated as CB1-5R and CB17R, were further analysed.

Two-dimensional (2D) electrophoresis. Control cells were grown in modified MRS at constant $\mathrm{pH} 6.4$ until the midexponential growth phase $\left(\mathrm{OD}_{620} 0.6\right)$ was reached and used for $2 \mathrm{D}$ electrophoresis without acid adaptation. The same growth conditions were used for the constitutively acidtolerant mutants. Acid-adapted cells were obtained after $60 \mathrm{~min}$ exposure of mid-exponential-phase cells in modified MRS adjusted to $\mathrm{pH} 5 \cdot 0$ with approximately $14 \mathrm{mM}$ lactic acid. Non-adapted (control) cells, lactic-acid-adapted cells and the acid-tolerant mutant cells were chilled on ice, diluted $1: 10$ with stop solution $(0 \cdot 1 \mathrm{M}$ Tris $/ \mathrm{HCl} \mathrm{pH} 7 \cdot 5$ containing $1 \mathrm{mg}$ chloramphenicol $\mathrm{ml}^{-1}$ ) and the suspensions were centrifuged at $4{ }^{\circ} \mathrm{C}$ and $15000 \mathrm{~g}$ for $10 \mathrm{~min}$. Harvested cells were

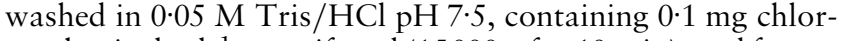
amphenicol ml $\mathrm{m}^{-1}$, centrifuged $(15000 \mathrm{~g}$ for $10 \mathrm{~min})$, and frozen or directly resuspended in denaturing buffer composed of $8 \mathrm{M}$ urea, $4 \%$ CHAPS, $40 \mathrm{mM}$ Tris base and $65 \mathrm{mM}$ dithioerythritol (DTE). Cells were disrupted with a Branson model B15 sonifier by four cycles of sonication (20 s each). After pelleting of unbroken cells $\left(15000 \mathrm{~g}\right.$ for $15 \mathrm{~min}$ at $\left.4{ }^{\circ} \mathrm{C}\right)$ the protein content was measured by the method of Bradford (1976). Two-dimensional gel electrophoresis was performed using the immobiline/polyacrylamide system, essentially as described by Görg et al. (1988) and Hochstrasser et al. (1988). The same amount of $60 \mu \mathrm{g}$ (analytical runs) or about $1 \mathrm{mg}$ (preparative runs for immunoblotting analysis) of total protein was used for each electrophoretic run. Isoelectric focusing was carried out on immobiline strips providing a non-linear 3-10 pH gradient (IPG strips, Amersham Pharmacia Biotech) by IPG-phore, at $15^{\circ} \mathrm{C}$. Voltage was increased from 300 to $5000 \mathrm{~V}$ during the first $5 \mathrm{~h}$, then stabilized at $8000 \mathrm{~V}$ for $8 \mathrm{~h}$. After electrophoresis, IPG strips were equilibrated for $12 \mathrm{~min}$ against $6 \mathrm{M}$ urea, $30 \%$ (w/v) glycerol, $2 \%$ SDS, $0.05 \mathrm{M}$ Tris $/ \mathrm{HCl}, \mathrm{pH} 6.8$ and $2 \% \mathrm{DTE}$, and for $5 \mathrm{~min}$ against $6 \mathrm{M}$ urea, $30 \%$ (w/v) glycerol, $2 \%$ SDS, $0.05 \mathrm{M}$ Tris/HCl, $\mathrm{pH} 6.8$, $2.5 \%$ iodoacetamide and $0.5 \%$ bromophenol blue. The second dimension was carried out in a Laemmli (1970) system on $9-16 \%$ polyacrylamide linear gradient gels $(18 \mathrm{~cm}$ $\times 20 \mathrm{~cm} \times 1.5 \mathrm{~mm}$ ), at $40 \mathrm{~mA}$ per gel constant current and $10{ }^{\circ} \mathrm{C}$ for approximately $5 \mathrm{~h}$ until the dye front reached the bottom of the gel. Preliminary SDS-PAGE runs at different linear concentrations and gradients of polyacrylamide were carried out to find the optimal protein separation. Under our experimental conditions, the gradient $9-16 \%$ polyacrylamide gave the best separation for high to medium molecular mass proteins. Gels were calibrated with two molecular mass markers: co-migration of the cell extracts with human serum proteins for the molecular mass range $200-10 \mathrm{kDa}$ and markers from Pharmacia Biotech for low molecular mass range $(16.9,14.4,10.7,8.2,6.2$ and $2.5 \mathrm{kDa})$. The electro- phoretic co-ordinates used for serum proteins were according to Bjellqvist et al. (1993). Analytical gels were silver stained as described by Hochstrasser et al. (1988) and Oakley et al. (1980). The protein maps were scanned with a laser densitometer (Molecular Dynamics 300s) and analysed with the Melanie II computer software (Bio-Rad). Four gels of independently grown replicates were analysed and spot intensities were normalized as reported by Bini et al. (1997). In particular, the spot quantification for each gel was calculated as relative volume (\% VOL): the volume of each spot divided by the total volume over the whole image. In this way, differences of the colour intensities among the gels were eliminated (Appel \& Hochstrasser, 1999). The induction factor was defined as the ratio between the spot intensity of the same protein in the adapted cells or mutant strains and in the non-adapted cells. All the induction factors were calculated based on the mean of the spot intensities of all four gels, with standard deviations. Only induction factors with a statistical significance at the $P<0.05$ level of probability are reported in Table 1. Since induction factors were calculated as means of four gels, some of the spot intensities of Figs $3(\mathrm{a}-\mathrm{d})$, which each show only one gel, may not visually agree with the induction factor values reported in Table 1.

Immunoblot analysis. Gels were electroblotted on nitrocellulose membranes according to Towbin et al. (1979) and further processed by standard procedures, modified as described by Bini et al. (1999) and Magi et al. (1999). Briefly, before immunodetection, the membranes were stained with $0.2 \%(\mathrm{w} / \mathrm{v})$ Ponceaus in $3 \%(\mathrm{w} / \mathrm{v})$ trichloroacetic acid for $3 \mathrm{~min}$ and the positions of selected landmark spots were marked on the membrane to assist subsequent matching of the immunoblots with the silver-stained map. Immunoreactive spots were detected by overnight incubation at room temperature with 1:2000 antibodies for DnaK, DnaJ and GrpE; 1:1000 for GroES, followed by incubation with 1:7000 conjugated peroxidase (Sigma), and revealed with a chemiluminescence based kit (ECL Pharmacia Amersham Biotech).

$\mathrm{N}$-terminal amino acid sequence determination. 2D maps were prepared as described above starting from $1 \mathrm{mg}$ sample per run, and blotted onto polyvinylidene difluoride membranes (Bio-Rad; $20 \times 20 \mathrm{~cm}, 0 \cdot 2 \mu \mathrm{m}$ pore size) according to Matsudaira (1987). The blots were stained with $0 \cdot 1 \%(\mathrm{w} / \mathrm{v})$ Coomassie brilliant blue R250 in $50 \%$ methanol for 5 min, and destained in $40 \%$ methanol, $10 \%$ acetic acid. Membranes were air-dried at $37^{\circ} \mathrm{C}$ and stored at $-20{ }^{\circ} \mathrm{C}$ for further analysis. Selected protein spots were cut out and submitted to amino acid sequencing by Edman degradation using an automatic protein/peptide sequencer (model 470A; Applied Biosystems) connected on-line with a phenylthiohydantoinamino acid analyser model 120A and a control/data module model 900A (Applied Biosystems) Typically three or four equivalent spots from similar blots were used, according to the estimated relative molar amount of protein in the spot. The programs included in the GCG package (Genetics Computer Group, Madison, WI, USA) were used for sequence analysis. BLAST and FASTA sequence comparisons were performed in the SWALL database.

Peptidase activity. Both non-adapted cells and constitutively acid-tolerant mutants were assayed for proteinase, aminopeptidase and iminopeptidase activities by using fluorescent casein, Lys- Leu-, Iso- and Pro-p-nitroanilide (NA) substrates, respectively (Gobbetti et al., 1997). The enzyme assays were carried out in $0.05 \mathrm{M}$ phosphate buffer $\mathrm{pH} 7.0$ and 5.5. One unit $(\mathrm{U})$ of proteinase activity was expressed as an increase of $0 \cdot 1$ unit of fluorescence per $10 \mathrm{~min}$. One unit of aminopeptidase and iminopeptidase activities was defined as an 
Table 1. Properties of acid-induced proteins after lactic acid adaptation or which are present in elevated amounts in the acid-tolerant mutants

Analysis was performed with the Melanie II computer software (Bio-Rad). Four gels of independently grown replicates were analysed. For spot quantification see Methods.

\begin{tabular}{|c|c|c|c|c|c|}
\hline \multirow{3}{*}{$\begin{array}{l}\text { Spot } \\
\text { designation* }\end{array}$} & \multirow[t]{3}{*}{ Estimated pI } & \multirow{3}{*}{$\begin{array}{l}\text { Estimated mol. } \\
\text { mass }(\mathrm{kDa})\end{array}$} & \multicolumn{3}{|c|}{ Induction factor $†$} \\
\hline & & & \multirow[t]{2}{*}{ Adapted cells } & \multicolumn{2}{|c|}{ Mutant strain } \\
\hline & & & & CB1-5R & CB1-7R \\
\hline 5 & $4 \cdot 52$ & $62 \cdot 4$ & $\mathrm{n}$ & $10 \pm 0 \cdot 3$ & $10 \pm 0 \cdot 5$ \\
\hline 8 & $5 \cdot 6$ & $60 \cdot 5$ & $3 \pm 0 \cdot 1$ & $2 \pm 0.05$ & $\mathrm{n}$ \\
\hline 16 & $6 \cdot 2$ & $36 \cdot 9$ & $2 \pm 0.06$ & $\mathrm{n}$ & $\mathrm{n}$ \\
\hline 17 & $4 \cdot 49$ & $36 \cdot 9$ & $2 \cdot 5 \pm 0 \cdot 08$ & $2 \pm 0.06$ & $\mathrm{n}$ \\
\hline 18 & $5 \cdot 68$ & $34 \cdot 4$ & $\mathrm{n}$ & $5 \pm 0 \cdot 08$ & $5 \pm 0 \cdot 15$ \\
\hline 19 & $4 \cdot 68$ & $34 \cdot 4$ & $2 \pm 0.07$ & $2 \pm 0 \cdot 05$ & $2 \pm 0 \cdot 06$ \\
\hline 22 & $7 \cdot 93$ & $33 \cdot 4$ & $\mathrm{n}$ & $10 \pm 0 \cdot 5$ & $10 \pm 0 \cdot 4$ \\
\hline 23 & $5 \cdot 08$ & $33 \cdot 3$ & $\mathrm{n}$ & $5 \pm 0.08$ & $5 \pm 0 \cdot 1$ \\
\hline 27 & $5 \cdot 87$ & $28 \cdot 7$ & $2 \cdot 5 \pm 0 \cdot 1$ & $10 \pm 0 \cdot 4$ & $8 \pm 0 \cdot 2$ \\
\hline 28 & $8 \cdot 02$ & $28 \cdot 6$ & $3 \pm 0 \cdot 1$ & $4 \pm 0 \cdot 15$ & $3 \pm 0 \cdot 2$ \\
\hline 33 & $4 \cdot 35$ & $25 \cdot 5$ & $\mathrm{n}$ & $10 \pm 0 \cdot 25$ & $10 \pm 0 \cdot 2$ \\
\hline 34 & $6 \cdot 5$ & $23 \cdot 0$ & $2 \pm 0 \cdot 07$ & $\mathrm{n}$ & $\mathrm{n}$ \\
\hline 36 & $5 \cdot 01$ & $22 \cdot 5$ & $3 \cdot 5 \pm 0 \cdot 1$ & $4 \pm 0.06$ & $4 \pm 0 \cdot 05$ \\
\hline 37 & $5 \cdot 60$ & $21 \cdot 8$ & $\mathrm{n}$ & $10 \pm 0 \cdot 3$ & $10 \pm 0 \cdot 5$ \\
\hline 39 & $7 \cdot 38$ & $21 \cdot 7$ & $\mathrm{n}$ & $10 \pm 0 \cdot 5$ & $10 \pm 0 \cdot 4$ \\
\hline 40 & $4 \cdot 35$ & $21 \cdot 7$ & $5 \pm 0 \cdot 15$ & $2 \pm 0 \cdot 01$ & $\mathrm{n}$ \\
\hline 41 & $8 \cdot 03$ & $21 \cdot 7$ & $4 \cdot 5 \pm 0 \cdot 2$ & $10 \pm 0 \cdot 25$ & $10 \pm 0 \cdot 4$ \\
\hline 42 & $4 \cdot 92$ & $19 \cdot 4$ & $\mathrm{n}$ & $10 \pm 0 \cdot 3$ & $10 \pm 0.5$ \\
\hline 43 & $4 \cdot 47$ & $19 \cdot 4$ & $2 \pm 0.09$ & $\mathrm{n}$ & $\mathrm{n}$ \\
\hline 44 & 6.74 & $18 \cdot 1$ & $2 \pm 0.08$ & $2 \pm 0.05$ & $3 \pm 0 \cdot 1$ \\
\hline 45 & $5 \cdot 26$ & $18 \cdot 1$ & $\mathrm{n}$ & $10 \pm 0 \cdot 4$ & $10 \pm 0 \cdot 5$ \\
\hline 46 & $5 \cdot 37$ & $17 \cdot 2$ & $\mathrm{n}$ & $7 \cdot 0 \pm 0 \cdot 1$ & $7 \cdot 5 \pm 0 \cdot 3$ \\
\hline 47 & $4 \cdot 49$ & $17 \cdot 2$ & $2 \cdot 5 \pm 0 \cdot 1$ & $\mathrm{n}$ & $\mathrm{n}$ \\
\hline 50 & $6 \cdot 09$ & $16 \cdot 0$ & $\mathrm{n}$ & $5 \pm 0 \cdot 18$ & $4 \pm 0 \cdot 2$ \\
\hline 51 & $5 \cdot 07$ & $15 \cdot 9$ & $\mathrm{n}$ & $2 \pm 0.05$ & $2 \pm 0.06$ \\
\hline 53 & $5 \cdot 36$ & $15 \cdot 3$ & $\mathrm{n}$ & $10 \pm 0 \cdot 5$ & $10 \pm 0 \cdot 4$ \\
\hline 54 & $5 \cdot 31$ & $13 \cdot 7$ & $2 \pm 0.06$ & $4 \pm 0.07$ & $3 \pm 0 \cdot 1$ \\
\hline 55 & $5 \cdot 57$ & $13 \cdot 0$ & $\mathrm{n}$ & $3 \pm 0 \cdot 1$ & $2 \pm 0.08$ \\
\hline 58 & $7 \cdot 85$ & $13 \cdot 0$ & $2 \pm 0.08$ & $3 \cdot 0 \pm 0 \cdot 25$ & $3 \cdot 5 \pm 0 \cdot 1$ \\
\hline 60 & $5 \cdot 23$ & $10 \cdot 9$ & $\mathrm{n}$ & $8 \cdot 0 \pm 0 \cdot 37$ & $7 \cdot 5 \pm 0 \cdot 1$ \\
\hline
\end{tabular}

* The numbers of the proteins correspond to those on the gels in Fig. $3(\mathrm{a}-\mathrm{d})$.

† The induction factor was defined as the ratio between the spot intensity of the same protein in the adapted cells or mutant strains and in the non adapted cells. All the induction factors were calculated based on the mean of the spot intensities of each four gels and are shown \pm SD. Only induction factors with a statistical significance at the $P<0.05$ level of probability were reported. n, No increase of the spot intensity with respect to the non-adapted cells detected.

increase of 0.01 unit of $A_{410}$ per min. Specific activities for all enzymes were determined as units of total activity per mg biomass. All the proteolytic activity results were expressed as the mean of at least five independent assays.

Partial purification of an intracellular aminopeptidase from Lb. sanfranciscensis CB1. Five litres of a $L b$. sanfranciscensis $\mathrm{CB} 1$ culture grown in modified MRS medium, $\mathrm{pH} 6.4$, at $30^{\circ} \mathrm{C}$ for $24 \mathrm{~h}$ were harvested by centrifugation and used for subcellular fractionation by lysozyme treatment in $50 \mathrm{mM}$ Tris/ $\mathrm{HCl}(\mathrm{pH} 7 \cdot 5$ ) buffer, containing $24 \%$ sucrose (Gobbetti et al., 1996). The cytoplasmic fraction was freeze-dried (MOD E1PTB, Edwards, Milan, Italy), concentrated 20-fold by resuspending in $20 \mathrm{mM}$ phosphate buffer ( $\mathrm{pH} \mathrm{6.5)}$ and dialysed for $24 \mathrm{~h}$ at $4{ }^{\circ} \mathrm{C}$ against the same buffer. This preparation was applied to a Q-Sepharose HR 16/50 column (Pharmacia-Biotech), previously equilibrated with $20 \mathrm{mM}$ phosphate buffer (pH 6.5). After loading, proteins were eluted with a linear $\mathrm{NaCl}$ gradient, $0-0.6 \mathrm{M}$, at a flow rate of $18 \mathrm{ml}$ $\mathrm{h}^{-1}$. The fractions with the highest aminopeptidase activity were pooled, dialysed for $24 \mathrm{~h}$ at $4{ }^{\circ} \mathrm{C}$ against distilled water, concentrated 10 -fold by freeze-drying, redissolved in a small 
volume of $50 \mathrm{mM}$ phosphate buffer ( $\mathrm{pH} \mathrm{6.5)} \mathrm{and} \mathrm{further}$ purified by gel filtration. A Sephacryl 200 column (PharmaciaBiotech), equilibrated with $50 \mathrm{mM}$ phosphate buffer ( $\mathrm{pH} \mathrm{6.5),}$ was used and elution with the same buffer was performed at a flow rate of $11 \mathrm{ml} \mathrm{h}^{-1}$. The most active fractions were pooled, dialysed, freeze-dried and resuspended in $20 \mathrm{mM}$ Bistrispropane ( $\mathrm{pH} 6.5)$. The last step of purification was carried out on an FPLC Mono Q HR 5/5 column (Pharmacia-Biotech). After loading of the sample, elution was performed with a linear gradient of $0-0.3 \mathrm{M} \mathrm{NaCl}$ at a flow rate of $0.75 \mathrm{ml} \mathrm{min}^{-1}$ with $20 \mathrm{mM}$ Bistris-propane $(\mathrm{pH} \mathrm{6.5)}$. The only fraction corresponding to the peak of aminopeptidase activity was dialysed, freeze-dried and used for 2D electrophoresis (see below). Aminopeptidase activity assays during purification steps were carried out by using Lys- $p$-NA as reported elsewhere.

Growth at $10{ }^{\circ} \mathrm{C}$ and in the presence of $5 \% \mathrm{NaCl}$. Growth at $10{ }^{\circ} \mathrm{C}$ was assayed by sudden transfer of mid-exponentialphase control, lactic-acid-adapted and constitutively acidtolerant mutant cells of $L b$. sanfranciscensis to modified MRS medium (initial $\mathrm{OD}_{620} 0 \cdot 2$ ) at $10^{\circ} \mathrm{C}$ and further incubation for $24 \mathrm{~h}$ at the same temperature. The ability of cultures to grow with high salt concentrations was examined by inoculating, in the same conditions, the control, lactic-acid-adapted and constitutively acid-tolerant mutant cells on modified MRS medium containing $5 \% \mathrm{NaCl}$ and incubating further at $30^{\circ} \mathrm{C}$ for $24 \mathrm{~h}$.

Sourdough fermentation. The characteristics of the wheat flour used were the same as those previously described (Gobbetti et al., 1999). Wheat flour (250 g), $110 \mathrm{ml}$ tap water and $40 \mathrm{ml}$ cell suspension containing approximately $\log 9 \cdot 0$ c.f.u. $\mathrm{ml}^{-1}$ of $L b$. sanfranciscensis CB1, CB1-5R or CB1-7R were used to produce $400 \mathrm{~g}$ dough (dough yield $=160$ ) with a continuous high-speed mixer $(60 \mathrm{~g})$ and mixing time of $5 \mathrm{~min}$. The cell suspensions of strains CB1, CB1-5R and CB1-7R were made by using mid-exponential-phase cells cultivated at constant $\mathrm{pH} 6.4$. The sourdough fermentation was carried out for $6 \mathrm{~h}$ at $30^{\circ} \mathrm{C}$ and the initial $\mathrm{pH}$ of the dough was 5.6 or 4.4 . The $\mathrm{pH} 4.4$ dough was obtained by adding a mixture of lactic and acetic acid in a molar ratio of $2 \cdot 3$. The initial cell concentration of lactobacilli in the dough was approximately $\log 7 \cdot 0$ c.f.u. $\mathrm{g}^{-1}$ as determined by plating on SDB agar medium. All the sourdough fermentation results were expressed as the mean of at least four independent assays.

Statistical analysis. All the data were analysed by a one-way analysis of variance. Statistical analyses were carried out using the SAS package (SAS Institute, 1985). Significant differences were defined at $P<0 \cdot 05$.

\section{RESULTS}

\section{Acid sensitivity of $L b$. sanfranciscensis CB1}

A mid-exponential-phase culture of strain CB1 was transferred to modified MRS medium at $\mathrm{pH} 4 \cdot 0,3 \cdot 8,3 \cdot 6$, 3.4 and $3 \cdot 2$, which was set by adding lactic acid or $\mathrm{HCl}$. Whereas the decrease in cell survival in the $\mathrm{pH}$ range $3 \cdot 6-4 \cdot 0$ was limited to two or less orders of magnitude, at both $\mathrm{pH} 3.4$ and $3 \cdot 2$ cell survival markedly decreased with increased incubation time (Fig. 1). At $\mathrm{pH}$ values higher than $4 \cdot 2$ cell survival did not decrease (data not shown). Lb. sanfranciscensis CB1 was less sensitive at $\mathrm{pH} 3.4$ when the $\mathrm{pH}$ was set by adding $\mathrm{HCl}$. A pH value of 3.4 set with lactic acid was chosen for subsequent experiments.

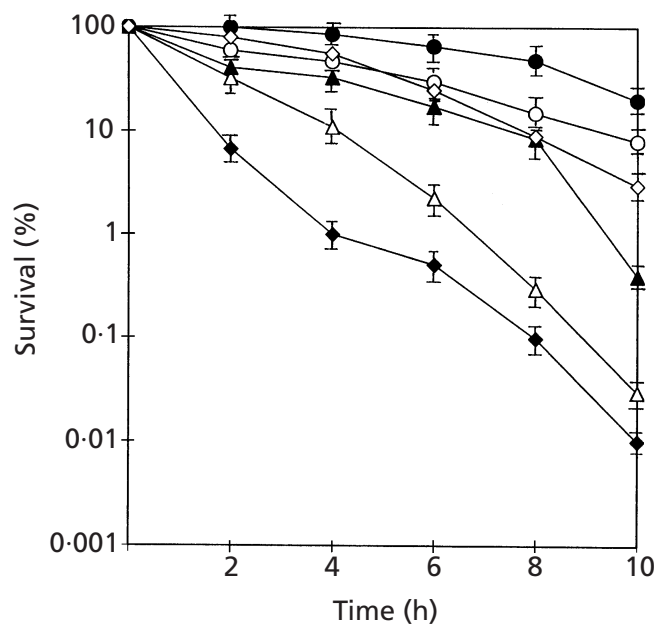

Fig. 1. Resistance of $L b$. sanfranciscensis $C B 1$ to a lactic acid stress at pH $4.0(\mathbf{O}), 3.8(\bigcirc), 3.6(\mathbf{\Delta}), 3.4(\triangle)$ and $3.2(\diamond)$, and to $\mathrm{HCl}$ stress at $\mathrm{pH} 3.4(\diamond)$. The data are means of four to six independent experiments; the bars indicate SD.

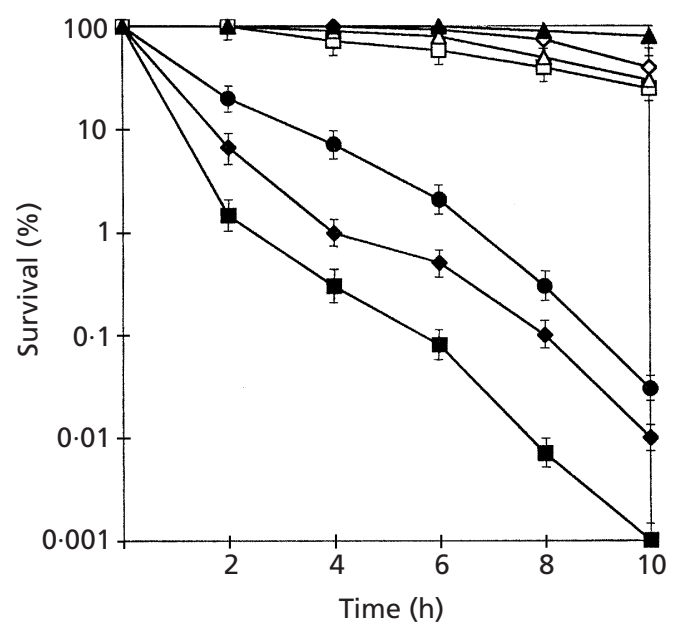

Fig. 2. The diamonds and squares show stress resistance of nonadapted (filled symbols) and $\mathrm{pH}$ 5.0-adapted (empty symbols) cells of $L b$. sanfranciscensis CB1 to a lactic acid $(\diamond, \diamond)$, and lactic plus acetic acid (molar ratio $2 \cdot 3)(\square, \square)$ stress at $\mathrm{pH} 3 \cdot 4$. $\boldsymbol{\Delta}, \triangle$ Stress resistance of mutant cells: CB1-5R $(\boldsymbol{\Delta})$ and $C B 1-7 R$ $(\triangle)$ to lactic acid stress at $\mathrm{pH} 3 \cdot 4$. Cells adapted at $\mathrm{pH} 5.0$ in the presence of $100 \mu \mathrm{g}$ chloramphenicol ml $\mathrm{m}^{-1}$. The data are means of four to six independent experiments; bars indicate SD.

\section{Adaptive response of $L b$. sanfranciscensis CB1 to acid pH}

Preliminary experiments at different $\mathrm{pH}$ values $(4 \cdot 5,5 \cdot 0$, 5.5 and $6 \cdot 0$, adjusted with lactic acid) for different times (30, 60 and $90 \mathrm{~min})$ showed that mid-exponential-phase cells ( $\mathrm{pH}$ 6.4) shifted to $\mathrm{pH} 5 \cdot 0$ for $1 \mathrm{~h}$ had the highest degree of resistance to subsequent acid challenges (data not shown). The tolerance factor induced by adaptation at $\mathrm{pH} 5 \cdot 0$ for $1 \mathrm{~h}$ was about $4 \times 10^{3}$ after $10 \mathrm{~h}$ exposure to the challenge $\mathrm{pH}$ (Fig. 2). When a mixture of lactic and acetic acid (molar ratio approx. 2.3) was used to 
produce the challenge $\mathrm{pH} 3 \cdot 4$, the tolerance factor increased to about $3 \times 10^{4}$. In agreement with other authors (O'Driscoll et al., 1997), the same tolerance factor was found by adaptation of cells to $\mathrm{pH} 5 \cdot 0$ either with the corresponding mixture of organic acids or with lactic acid alone. All these results did not vary when the challenge $\mathrm{pH}$ was $3 \cdot 2$ (data not shown). When $100 \mu \mathrm{g}$ chloramphenicol ml$l^{-1}$, which is bacteriostatic and blocks protein synthesis, were added during the adaptive shift to $\mathrm{pH} 5 \cdot 0(1 \mathrm{~h})$, the tolerance factor decreased to less than 10 (Fig. 2). The incubation of $L b$. sanfranciscensis CB1 cells with chloramphenicol at $\mathrm{pH} 6.4$ for 10-60 min before adaptation at $\mathrm{pH} \mathrm{5.0} \mathrm{did} \mathrm{not}$ prevent the adaptive response to the acid challenge (data not shown).

\section{Isolation of acid-tolerant mutants of $L b$. sanfranciscensis CB1}

Constitutively acid-tolerant mutants of $L b$. sanfranciscensis CB1 were isolated following prolonged exposure $(24 \mathrm{~h})$ to the challenge $\mathrm{pH} 3 \cdot 2$. Survivors were grown at $\mathrm{pH} 6.4$ and repeatedly screened for acid resistance. Seven such isolates exhibited an acid-tolerant phenotype; two of them, CB1-5R and CB1-7R, were further used in this study. The mutants were acid tolerant as the adapted parental cells (Fig. 2), although CB1-7R had a slightly lower survival than CB1-5R during the last few hours of incubation.

\section{D analysis of acid-induced modifications in protein synthesis}

Compared to the whole-cell protein extracts of the non-adapted cells, the modifications found in the acidadapted CB1 and the constitutively acid-tolerant mutants (CB1-5R and CB1-7R) concerned 63 proteins (Fig. 3a-d, Table 1). The synthesis of 17 proteins, which were mainly located at $\mathrm{pI}$ around 6.7 and molecular mass of approximately $10-28 \mathrm{kDa}$, decreased in the acid-adapted cells. Eight of these proteins also showed reduction in the constitutively acid-tolerant mutants CB1-5R and CB1-7R, which also showed a decrease in the expression of 16 (CB1-5R) or 14 (CB1-7R) other proteins, which mainly had molecular masses greater than $33 \mathrm{kDa}$. On the other hand, 15 proteins in the acidadapted cells and 26 proteins in the acid-tolerant mutant CB1-5R (11 of which were common) increased in amount compared to non-adapted cells. Protein 40 was markedly expressed in the acid-adapted cells, showing the highest induction factor among the proteins that were specifically induced in this strain. Interestingly, the constitutively acid-tolerant mutants had a very similar level of protein expression, which only differed for proteins $8,17,40,52$ and 59 .

\section{Identification of heat-shock proteins by Western blotting}

Antibodies against DnaK, DnaJ and GroES detected single proteins with experimental molecular masses of 70,60 and $10 \cdot 7 \mathrm{kDa}$ and pIs of $4 \cdot 4,7 \cdot 82$ and $7 \cdot 5$, respectively (Fig. 3a-d). There were no appreciable differences in the level of expression of these three proteins among the non-adapted, acid-adapted and acidtolerant mutant cells. Antibodies against GrpE reacted with three proteins. Based on the 2D-electrophoretic coordinates of $L b$. acidophilus, $L b$. casei, Lb. helveticus and Lc. lactis homologues (Broadbent et al., 1997; Hartke et al., 1996), protein 36 was identified as GrpE (Fig. 3a-d, Table 1). It showed an induction factor of 3.5 and 4 in the acid-adapted cells and the acid-tolerant mutants, respectively.

\section{Identification of proteins separated by 2D electrophoresis by $\mathrm{N}$-terminal amino acid sequencing}

Protein 19, which showed a similar induction factor in both the acid-adapted cells and acid-tolerant mutants, and protein 40, which had the highest induction factor among those proteins specifically induced in the acidadapted cells and was also expressed in the consitutively acid-tolerant mutant CB1-5R, were subjected to Nterminal sequencing. The sequences were XKEYND and SFKKGLFLGTILGGAA, respectively. Regarding protein 40 , comparison of the 15 amino acid sequence with protein databases revealed a $60 \%$ identity with the $\mathrm{N}$-terminal portion of $\mathrm{YhaH}$, a $13.1 \mathrm{kDa}$ hypothetical protein of Bacillus subtilis (Kunst et al., 1997).

The SWISS-PROT accession numbers for the acidshock proteins are P82648 for spot 40 and P82655 for spot 19.

\section{Peptidase activity of acid-tolerant mutants and partial purification of an intracellular aminopeptidase}

As stated by other authors (Chou \& Weimer, 1998), in addition to the main character selected (acid tolerance), the presence of multiple phenotypic changes is frequent in selected mutants. Compared to non-adapted cells of strain CB1, the mutants CB1-5R and CB1-7R had a variable aminopeptidase and iminopeptidase activity: $10 \cdot 1 \pm 0 \cdot 8$ and $23 \cdot 6 \pm 1 \cdot 2$ vs $16 \cdot 8 \pm 1 \cdot 0$, and $6 \cdot 2 \pm 0 \cdot 5$ and $11 \cdot 4 \pm 0.7$ vs $6 \cdot 3 \pm 0 \cdot 2 \mathrm{U} \mathrm{mg}^{-1}$, respectively. In particular, the difference in the aminopeptidase activity between mutant CB1-7R and the non-adapted cells was enhanced when the enzyme assays was conducted at $\mathrm{pH} 5 \cdot 5$ : $37 \cdot 2 \pm 1.5$ vs $9.5 \pm 0.7 \mathrm{U} \mathrm{mg}^{-1}$. The aminopeptidase activity did not vary when Lys-, Leu- and Iso- $p$-NA substrates were used. The proteinase activity did not differ between the three strains.

An intracellular aminopeptidase from the cytoplasmic extract of $L b$. sanfranciscensis CB1 was partially purified by three chromatographic steps. The fraction which contained the highest aminopeptidase activity after elution on an FPLC Mono Q column was subjectd to 2D electrophoresis. It contained four proteins with experimental molecular masses of $75,23,22 \cdot 1$ and $17 \cdot 8 \mathrm{kDa}$ and pIs of $4 \cdot 88,5 \cdot 6,6 \cdot 74$ and $4 \cdot 95$, respectively (data not shown). These proteins corresponded to spots located in the same position of the whole-cell protein extracts of 

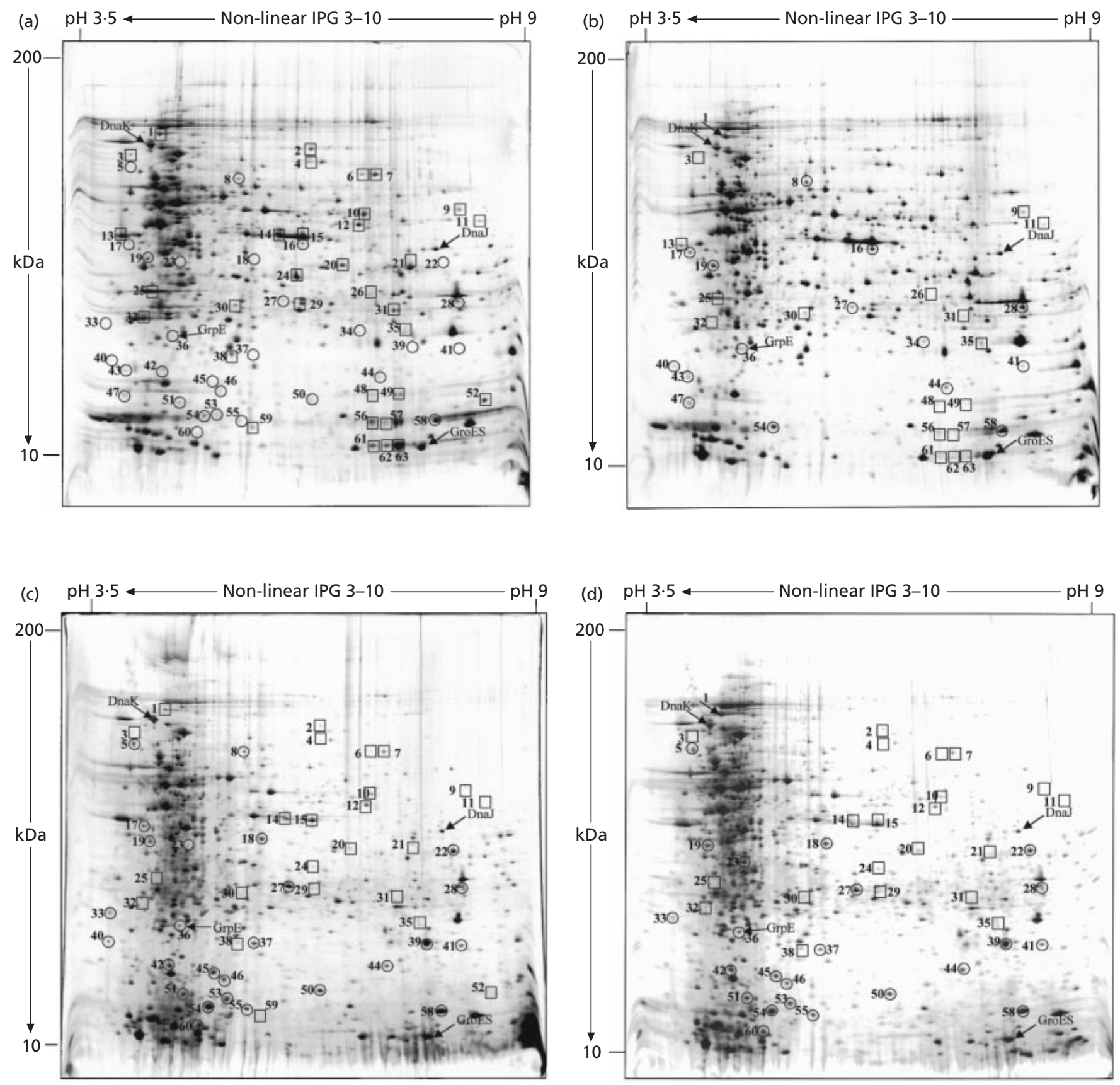

Fig. 3. $2 \mathrm{D}$ electrophoresis analysis of protein expression in Lb. sanfranciscensis CB1. (a) Cells grown at constant $\mathrm{pH} 6 \cdot 4$ (non-adapted cells); (b) cells adapted at $\mathrm{pH} 5.0$ for $1 \mathrm{~h}$ with lactic acid (acid-adapted); (c, d) constitutively acid-tolerant mutants CB1-5R (c) and CB1-7R (d). Numbered squares and circles refer to proteins which are present in decreased and increased amounts, respectively, compared to non-adapted cells. The positions of proteins which reacted with antibodies against DnaJ, DnaK, GroES and GrpE are indicated.

non-adapted, acid-adapted and constitutively acid-tolerant mutant cells. In particular, the protein with a molecular mass of $75 \mathrm{kDa}$ and $\mathrm{pI} 4.88$ corresponds to spot 1 of Fig. $3(\mathrm{a}-\mathrm{d})$. In a previous paper dealing with the proteolytic system of $L b$. sanfranciscensis CB1 (Gobbetti et al., 1996), a $75 \mathrm{kDa}$ intracellular aminopeptidase was purified to homogeneity and characterized.

\section{Growth at $10{ }^{\circ} \mathrm{C}$ and in the presence of $5 \% \mathrm{NaCl}$}

Non-adapted, acid-adapted and constitutively acidtolerant mutant cells of $L b$. sanfranciscensis CB1 were also assayed for growth at $10{ }^{\circ} \mathrm{C}$ and in the presence of $5 \% \mathrm{NaCl}$, which represent restrictive conditions for the storage and use of sourdough lactobacilli. Both acidadapted and mutant cells showed a moderately higher 


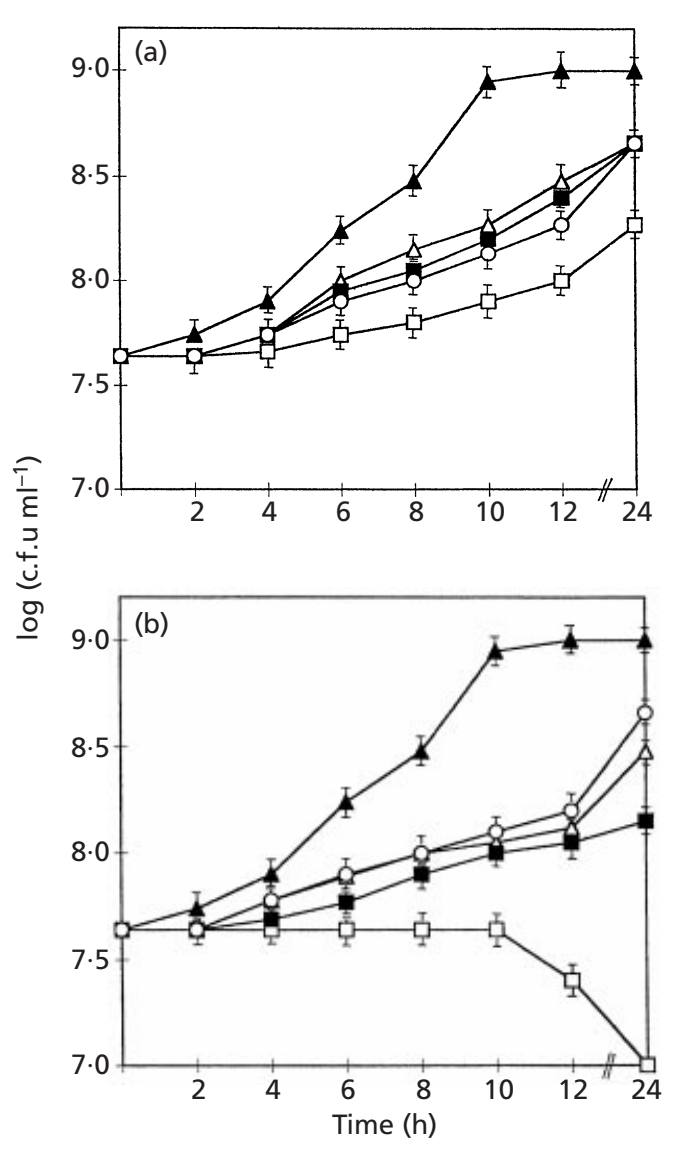

Fig. 4. Growth of non-adapted ( $\square$ ), pH 500-adapted ( $\square$ ) and non-adapted mutant cells [CB1-5R $(O)$ and CB1-7R $(\triangle)$ ] of $L b$. sanfranciscensis $\mathrm{CB} 1$ in modified MRS at $10^{\circ} \mathrm{C}$ (a) and in the presence of $5 \% \mathrm{NaCl}$ at $30^{\circ} \mathrm{C}$ (b). $\mathbf{\Delta}$, Typical growth curve of $L b$. sanfranciscensis $\mathrm{CB} 1$ in the absence of $\mathrm{NaCl}$ and at $30^{\circ} \mathrm{C}$. The data are means of four to six independent experiments; bars indicate SD.

growth at $10{ }^{\circ} \mathrm{C}$ compared to non-adapted cells (Fig. $4 a)$. The final cell concentration was approximately $8 \cdot 6$ vs $8.1 \log$ c.f.u. $\mathrm{ml}^{-1}$, respectively. These differences were enhanced after growth in modified MRS containing $5 \% \mathrm{NaCl}$, which seemed to be lethal for non-adapted cells (Fig. 4b). Acid-adapted and, especially, mutant cells grew in this culture condition, whereas nonadapted cells of $L b$. sanfranciscensis CB1 did not grow during the first $10 \mathrm{~h}$ of incubation, then showed a decrease of viability. After $24 \mathrm{~h}$ of incubation, the constitutively acid-tolerant mutant CB1-5R had a cell concentration of approximately $8.6 \mathrm{vs} 7 \cdot 0$ c.f.u. $\mathrm{ml}^{-1}$ for the non-adapted cells.

\section{Sourdough fermentation}

Sourdoughs produced by strains CB1, CB1-5R and CB1$7 \mathrm{R}$ were compared. If the initial $\mathrm{pH}$ of the dough was $5 \cdot 6$, CB1 lowered the $\mathrm{pH}$ to $3 \cdot 86 \pm 0.02$ as compared to $3.97 \pm 0.02$ with strain CB1-7R after 6 h of fermentation. However, if the initial $\mathrm{pH}$ was $4 \cdot 4$ the sourdough produced with acid-tolerant mutant CB1-7R reached pH $3.64 \pm 0.02$ compared to $3.97 \pm 0.03$ with the parental strain CB1. While no differences in the cell concentration were found during the sourdough fermentation started at $\mathrm{pH} 5.6$ (approx. $\log 8.5$ c.f.u. $\mathrm{g}^{-1}$ ), when the initial $\mathrm{pH}$ was 4.4 the cell concentration of lactobacilli increased from approximately $\log 7 \cdot 0$ to $8 \cdot 2$ c.f.u. $\mathrm{g}^{-1}$ in the dough started with CB1-7R and there was no growth when the parental strain CB1 was used. Mutant CB1-5R behaved similarly to CB1-7R.

\section{DISCUSSION}

During routine use, sourdough bacteria are subjected to several stresses (e.g. osmotic, starvation and low temperature). Acid stress is probably the most relevant to the sourdough process because it may interfere with the microbial composition and therefore with the performance of the sourdough during straight or repeated use (Gobbetti, 1998). The availability of acid-adapted cells or acid-tolerant mutants could greatly improve the efficacy and consistency of industrial sourdough production. To our knowledge, no studies have yet been published on the stress responses of sourdough lactobacilli. Furthermore, studies on the acid-stress responses of lactobacilli, which have only considered $L b$. acidophilus (Chou \& Weimer, 1998) and Lb. plantarum (McDonald et al., 1990), did not analyse changes in their protein expression patterns.

\section{Acid-stress response}

Overall, Lb. sanfranciscensis CB1 showed an inherent acid tolerance higher than that of dairy lactic acid bacteria. Whereas lactococcal strains were characterized by a very low acid resistance to a $\mathrm{pH}$ of approximately 4.0 (Hartke et al., 1996; Rallu et al., 1996), the same $\mathrm{pH}$ value had only a slight effect on the survival of this sourdough bacterium. Although the $\mathrm{pH}$ of fermented foods does not necessarily correlate with cell survival, in the case of $L b$. sanfranciscensis $\mathrm{CB} 1$ it seems in agreement with the very high acidity $(\mathrm{pH} 3 \cdot 3-3 \cdot 7)$ which usually characterizes sourdough at the end of fermentation (Gobbetti, 1998).

The survival of $L b$. sanfranciscensis CB1 decreased dramatically when cells grown at constant $\mathrm{pH} 6.4$ were suddenly subjected to $\mathrm{pH} 3 \cdot 2-3 \cdot 4$. The effect of various acids on the survival and therefore on the intracellular $\mathrm{pH}$ of $L b$. sanfranciscensis CB1 varied.

The acid-stress tolerance of $L b$. sanfranciscensis CB1 depended on the induction of protein synthesis. The tolerance markedly decreased when a bacteriostatic concentration of chloramphenicol $\left(100 \mu \mathrm{g} \mathrm{ml}^{-1}\right)$ was added during adaptation. The incubation of $L b$. sanfranciscensis with chloramphenicol for 10-60 min at $\mathrm{pH} 6 \cdot 4$, subsequent washing of the cells and further adaptation did not prevent adaptive response to the acid challenge, meaning that probably proteins synthesized before exposure to the sublethal $\mathrm{pH} 5 \cdot 0$ were not directly 
responsible for the acid-stress tolerance. Similar results were obtained by studying the acid-stress response of $L c$. lactis (O'Sullivan \& Condon, 1997, 1999; Rallu et al., 1996) and Listeria monocytogenes (O'Driscoll et al., 1997).

The acid-adapted cells and the acid-tolerant mutant showed similarities by $2 \mathrm{D}$ analysis: 8 proteins which decreased as well as 8 or 11 proteins (depending on the mutant) which increased their level of expression as compared to the non-adapted cells were common. Several proteins were highly induced only in the lacticacid-adapted cells or in the acid-tolerant mutant (induction factors from 5 to 10). A comparison between the two mutants revealed that among a total of 27 proteins (CB1-5R plus CB1-7R) overexpressed compared to the parental CB1, 21 showed no significant differences in the level of expression between the two mutants, 3 varied slightly and only 3 were overexpressed in either one or the other strain (Table 1). This suggests that most of these overexpressed proteins in the two mutants are involved in the acid-stress response.

The $\mathrm{N}$-terminal sequence of protein 19, whose expression showed about the same induction factor in the acid-adapted cells and in the acid-tolerant mutants of Lb. sanfranciscensis (Fig. 3a-d, Table 1), did not show significant homology with any proteins in the BLAST and FASTA sequence comparisons of the SWALL database. The $\mathrm{N}$-terminal sequence of protein 40 , whose expression showed the highest induction factor among the proteins specifically induced in the lactic-acid-adapted cells and was also induced in mutant CB1-5R, has $60 \%$ identity with the sequence of $\mathrm{YhaH}$, a $13 \cdot 1 \mathrm{kDa}$ protein deduced from the genome sequence of B. subtilis. The 15 amino acid overlap alignment is located in the $\mathrm{N}$ terminal portion, where $\mathrm{YhaH}$ shows a potential transmembrane helix. Although the function of $\mathrm{YhaH}$ is still unknown, this B. subtilis protein shares $54 \%$ homology with a 174 amino acid stress protein identified in Listeria monocytogenes (EMBL accession number AF102167) and $47 \%$ with a 144 amino acid general stress protein from Bacillus halodurans (Takami et al., 2000).

Genes involved in the heat-shock response are highly conserved and the related DnaK-DnaJ-GrpE and GroEL-GroES chaperone complexes are not only induced by heat shock but also by other types of stress, including acidity (Hartke et al., 1996, 1997; Rallu et al., 1996). In the lactobacilli Lb. acidophilus, Lb. casei and $L b$. helveticus, DnaK was the only chaperonin whose expression increased in all three species (expression of GrpE increased only in Lb. helveticus and DnaJ did not vary its expression) when heat-shocked cells were compared to control cells (Broadbent et al., 1997). Antibodies against DnaJ, DnaK, GroES and GrpE were used in this study. In contrast with most of the reports cited, the proteins which reacted with DnaJ, DnaK and GroES antisera did not vary in their levels of expression when the whole-cell protein extracts of acid-adapted or acid-tolerant mutant cells were compared with those of the non-adapted cells of $L b$. sanfranciscensis CB1. Only
GrpE seemed to be a general stress-response protein in $L b$. sanfranciscensis $\mathrm{CB} 1$ since it was induced by a factor of $3 \cdot 5-4 \cdot 0$.

\section{Other phenotypic features of the constitutively acid-tolerant mutants}

Certain Lb. acidophilus mutants have been proposed as suitable probiotic strains because they have enhanced acid and bile tolerance (Chou \& Weimer, 1998). These $L b$. acidophilus mutants also differed from the parental strain in having higher stability to freezing, and especially in their lower efficient lactose utilization, and peptidase and proteinase activities (Chou \& Weimer, 1998). Compared to the parental strain, $L b$. sanfranciscensis CB1-5R and CB1-7R had an inherent acid tolerance and also varied in two peptidase activities. While CB1-5R had a lower aminopeptidase activity, CB1-7R showed much higher aminopeptidase and iminopeptidase activities compared to the parental strain CB1, especially in acid conditions ( $\mathrm{pH} 5 \cdot 5)$. Peptidase activities during sourdough fermentation are of great importance since they are involved in the microbial growth and in the synthesis of amino acids which are directly or indirectly responsible for bread flavour formation (Gobbetti, 1998).

Looking for aminopeptidase activity, the cytoplasmic extract of $L b$. sanfranciscensis CB1 was purified by three chromatographic steps. The 2D electrophoresis gel showed the presence of four proteins, one of which had an experimental molecular mass of $75 \mathrm{kDa}$ and $\mathrm{pI}$ of 4.88. This protein coincided with spot 1 of Fig. $3(\mathrm{a}-\mathrm{d})$ and with the aminopeptidase activity. Indeed in a previous report (Gobbetti et al., 1996) we purified a monomeric $75 \mathrm{kDa}$ intracellular metallo-aminopeptidase from $L b$. sanfranciscensis CB1 which, as in this report, had the same activity on Lys-, Leu- and Iso$p$-NA as preferential substrates. The level of expression of this protein was the same in all the strains, except for mutant CB1-5R, where the expression was about three times less. This may be related to the great difference found in the aminopeptidase activities between the two mutants. In contrast, the higher aminopeptidase activity of mutant CB1-7R compared to the parent CB1 is not related to the level of protein expression but probably based on the inherent adaptability of the mutant to acid conditions.

Lc. lactis subsp. cremoris (O'Sullivan \& Condon, 1997) and Listeria monocytogenes (O'Driscoll et al., 1996) cells showed an acid-induced multistress tolerance against heat, ethanol, $\mathrm{NaCl}$ and $\mathrm{H}_{2} \mathrm{O}_{2}$. Under our conditions, acid-adapted and, especially, mutant cells grew better than non-adapted cells at $10^{\circ} \mathrm{C}$ and in the presence of $5 \% \mathrm{NaCl}$. The prolonged incubation in modified MRS, pH 6.4, containing $5 \% \mathrm{NaCl}$ was found to be lethal for non-adapted cells. The storage of sourdough at refrigeration temperatures before subsequent use is a common practice as is the production of salted (approx. $2-5 \% \mathrm{NaCl}$ ) sourdough breads. The 
addition of salt to the dough can moderately decrease the acidification rate of sourdough lactic acid bacteria, and to have selected acid and salt-tolerant strains certainly improves the sourdough fermentation.

When used in sourdough fermentation, the acid-tolerant mutants $L b$. sanfranciscensis CB1-5R and CB1-7R had some advantages. The sourdough fermentation may require several and different processing steps, one of which is the addition of fresh lactic acid bacteria cells to a partially acidified dough $(\mathrm{pH} 4 \cdot 5-5 \cdot 0)$ in order to promote a rapid fermentation before baking. A fast acidification rate in these conditions reduces the risk of microbial contamination and also makes the sourdough competitive compared to bakers' yeast by decreasing the fermentation time (Gobbetti, 1998). Under our conditions, when the initial $\mathrm{pH}$ of the dough was $4 \cdot 5$, the use of the acid-tolerant mutants CB1-5R and CB1-7R gave a faster and higher acidification rate than the parental strain CB1.

\section{Conclusions}

The acid-stress response in Lb. sanfranciscensis CB1, a key sourdough lactic acid bacterium, was investigated: (i) it tolerated low $\mathrm{pH}$ after initial exposure to sublethal acid conditions; (ii) protein synthesis was required for the acid tolerance; (iii) two constitutively acid-tolerant mutants were isolated which also differed for peptidase activity; (iv) 2D electrophoresis analyses revealed large changes in the level of protein expression of acidadapted and mutant cells compared to the parental strain; (v) the level of protein expression in two mutants was very similar; (vi) among proteins involved in heatshock response, only GrpE was induced in acid conditions; (vii) the N-terminal sequence of a protein with the highest induction factor in the acid-adapted cells showed some similarity with known bacterial acid or general stress proteins; and (viii) the use of acid-tolerant mutants during sourdough fermentation in acid conditions gave some advantages. The current findings are the basis for further molecular cloning studies to enhance the exploitation of the physiology of sourdough lactobacilli.

\section{REFERENCES}

Appel, D. \& Hochstrasser, D. F. (1999). Computer analysis of 2-D images. Methods Mol Biol 112D, 431-443.

Bini, L., Magi, B., Marzocchi, B. \& 9 other authors (1997). Protein expression profiles in human breast ductal carcinoma and histologically normal tissue. Electrophoresis 18, 2832-2841.

Bini, L., Liberatori, S., Magi, B., Marzocchi, B., Raggiaschi, R. \& Pallini, V. (1999). Protein blotting and immunoblotting, p.127-141. In Proteome Research: Two-dimensional Gel Electrophoresis and Identification Methods, vol. 1, pp. 127-141. Edited by T. Rabilloud. New York: Springer.

Bjellqvist, B., Hughes, G. J., Pasquali, C., Paquet, N., Ravier, F., Sanchez, J.-C., Frutiger, S. \& Hochstrasser, D. (1993). The focusing positions of polypeptides in immobilized $\mathrm{pH}$ gradients can be predicted from their amino acid sequences. Electrophoresis 14, 1023-1031.

Bradford, M. M. (1976). A rapid and sensitive method for the quantitation of microgram quantities of protein utilizing the principle of protein-dye binding. Anal Biochem 72, 248-254.

Broadbent, J. R., Oberg, J. C., Wang, H. \& Wei, L. (1997). Attributes of the heat shock response in three species of dairy Lactobacillus. Syst Appl Microbiol 20, 12-19.

Chou, L. \& Weimer, B. (1998). Isolation and characterization of acid and bile-tolerant isolates from strains of Lactobacillus acidophilus. J Dairy Sci 82, 23-31.

Diamant, S. \& Goloubinoff, P. (1998). Temperature-controlled activity of DnaK-DnaJ-GrpE concentration. Biochemistry 37, 9688-9694.

Duwat, P., Ehrlich, S. D. \& Gruss, A. (1995). The recA gene of Lactococcus lactis: characterization and involvement in oxidative and thermal stress. Mol Microbial 17, 1121-1131.

Duwat, P., Ehrlich, S. D. \& Gruss, A. (1999). Effects of metabolic flux on stress response pathways in Lactococcus lactis. Mol Microbiol 31, 845-858.

Foster, J. W. (1999). When protons attack: microbial strategies of acid adaptation. Curr Opin Microbiol 2, 170-174.

Frees, D. \& Igmer, H. (1999). ClpP participates in the degradation of misfolden protein in Lactococcus lactis. Mol Microbiol 31, 79-87.

Glaasker, E., Tjan, F. S. B., Tergesteeg, P. F., Konings, W. N. \& Poolman, B. (1998). Physiological response of Lactobacillus plantarum to salt and nonelectrolyte stress. J Bacteriol 180, 4718-4723.

Gobbetti, M. (1998). The sourdough microflora: interactions of lactic acid bacteria and yeasts. Trends Food Sci Technol 9, 267-274.

Gobbetti, M., Smacchi, E. \& Corsetti, A. (1996). The proteolytic system of Lactobacillus sanfrancisco CB1: purification and characterization of a proteinase, dipeptidase and aminopeptidase. Appl Environ Microbiol 62, 3220-3226.

Gobbetti, M., Lowney, S., Smacchi, E., Battistotti, B., Damiani, P. \& Fox, P. F. (1997). Microbiology and biochemistry of Taleggio cheese during ripening. Int Dairy J 7, 509-517.

Gobbetti, M., De Angelis, M., Arnaut, P., Tossut, P., Corsetti, A. \& Lavermicocca, P. (1999). Added pentosans in breadmaking: fermentation of derived pentoses by sourdough lactic acid bacteria. Food Microbiol 16, 409-418.

Görg, A., Postel, W. \& Gunther, S. (1988). The current state of two-dimensional electrophoresis with immobilized $\mathrm{pH}$ gradients. Electrophoresis 9, 531-546.

Hartke, A., Bouché, S., Giard, J. C., Benachour, A., Boutibonnes, P. \& Auffray, Y. (1996). The lactic acid stress response of Lactococcus lactis subsp. lactis. Curr Microbiol 33, 194-199.

Hartke, A., Frère, J., Boutibonnes, P. \& Auffray, J. (1997). Differential induction of the chaperonin GroEL and the cochaperonin GroES by heat, acid, and UV-irradiation in Lactococcus lactis subsp. lactis. Curr Microbiol 34, 23-26.

Hecker, M., Schumann, W. \& Völker, U. (1996). Heat-shock and general stress response in Bacillus subtilis. Mol Microbiol 19, $417-428$.

Hochstrasser, D. F., Harrington, M. G., Hochstrasser, A. C., Miller, M. J. \& Merril, C. R. (1988). Methods for increasing the resolution of two dimensional protein electrophoresis. Anal Biochem 173, 424-435.

Kim, S. W., Ren, J. \& Dunn, N. W. (1999). Differentation of Lactococcus lactis subspecies lactic and cremoris strains by their adaptive response to stresses. FEMS Microbiol Lett 171, 57-65.

Kline, L. \& Sugihara, T. F. (1971). Microorganisms of the San 
Francisco sour dough bread process. II. Isolation and characterization of undescribed bacterial species responsible for souring activity. Appl Microbiol 21, 459-465.

Konings, W. N., Lolkema, J. S., Bolhuis, H., van Veen, H. V., Poolman, B. \& Driessen, A. J. M. (1997). The role of transport processes in survival of lactic acid bacteria. Antonie Leeuwenhoek 71, 117-128.

Kunst, F., Ogsawara, N., Moszer, I. \& 148 other authors (1997). The complete genome sequence of the gram-positive bacterium Bacillus subtilis. Nature 390, 249-256.

Laemmli, U. K. (1970). Cleavage of structural proteins during the assembly of the head of bacteriophage T4. Nature 227, 680-685.

Magi, B., Bini, L., Marzocchi, B., Liberatori, S., Raggiaschi, R. \& Pallini, V. (1999). Immunoaffinity identification of 2-DE separated proteins. Methods Mol Biol 112D, 431-443.

Matsudaira, P. (1987). Sequence from picomole quantities of proteins electroblotted onto polyvinylidene difluoride membranes. J Biol Chem 262, 10035-10038.

McDonald, L. C., Fleming, H. P. \& Hassan, H. M. (1990). Acid tolerance of Leuconostoc mesenteroides and Lactobacillus plantarum. Appl Environ Microbiol 56, 2120-2124.

Oakley, B. R., Kirsch, D. R. \& Morris, R. (1980). A simplified ultrasensitive silver stain for detecting proteins in polyacrylamide gels. Anal Biochem 105, 361-363.

O’Driscoll, B., Gahan, C. G. M. \& Hill, C. (1996). Adaptive acid tolerance response in Listeria monocytogenes: isolation of an acid-tolerant mutant which demonstrates increased virulance. Appl Environ Microbiol 62, 1693-1698.

O’Driscoll, B., Gahan, C. G. M. \& Hill, C. (1997). Two-dimensional polyacrylamide gel electrophoresis analysis of the acid tolerance response in Listeria monocytogenes LO28. Appl Environ Microbiol 63, 2679-2685.

O'Sullivan, E. \& Condon, S. (1997). Intracellular $\mathrm{pH}$ is a major factor in the induction of tolerance to acid and other stresses in Lactococcus lactis. Appl Environ Microbiol 63, 4210-4215.

O'Sullivan, E. \& Condon, S. (1999). Relationship between acid tolerance, cytoplasmic $\mathrm{pH}$, and ATP and $\mathrm{H}^{+}$- ATPase levels in chemostat cultures of Lactococcus lactis. Appl Environ Microbiol 65, 2287-2293.

Rallu, F., Gruss, A. \& Maguin, E. (1996). Lactococcus lactis and stress. Antonie Leeuwenhoek 70, 243-251.

SAS Institute (1985). SAS User Guide: Statistics, version 5. Cary, NC: SAS Institute.

Smeds, A., Varmanen, P. \& Palva, A. (1998). Molecular characterization of a stress-inducible gene from Lactobacillus helveticus. J Bacteriol 180, 6148-6153.

Takami, H., Nakasone, K., Takaki, Y. \& 9 other authors (2000). Complete genome sequence of the alkaliphilic bacterium Bacillus halodurans and genomic sequence comparison with Bacillus subtilis. Nucleic Acids Res 28, 4317-4331.

Towbin, H., Staehelin, T. \& Gordon, J. (1979). Electrophoretic transfer of proteins from polyacrylamide gels to nitrocellulose sheets: procedure and some applications. Proc Natl Acad Sci US A 76, 4350-4354.

Received 6 February 2001; revised 21 March 2001; accepted 30 March 2001. 